University of Warwick institutional repository: http://go.warwick.ac.uk/wrap

This paper is made available online in accordance with publisher policies. Please scroll down to view the document itself. Please refer to the repository record for this item and our policy information available from the repository home page for further information.

To see the final version of this paper please visit the publisher's website. Access to the published version may require a subscription.

Author(s): Mah, Alice

Article Title: Devastation but also home: place attachment in areas of industrial decline

Year of publication: 2009

Link to published article :

http://dx.doi.org/10.2752/174063109X12462745321462

Publisher statement: This is not the final published version. The published version can be found at http://www.bergpublishers.com/

Mah, A. (2009). Devastation but also home : place attachment in areas of industrial decline. Home Cultures, 6(3), pp. 287-310. 


\title{
Devastation but also home: place attachment in areas of industrial decline
}

\author{
Dr Alice Mah \\ Department of Sociology \\ University of Warwick \\ Coventry CV4 7AL \\ a.a.mah@warwick.ac.uk
}

\begin{abstract}
This article analyses the phenomenon of place attachment to 'home' in two areas of industrial decline: Walker, Newcastle-upon-Tyne (UK) and Highland, Niagara Falls, New York (US). The research contributes to theoretical and empirical literatures from sociology, anthropology, geography, environmental psychology, and material culture studies on notions of place, community, memory and home. Despite socioeconomic deprivation and material devastation in areas of industrial decline, houses and neighbourhood spaces can become invested with notions of family and community unity, nostalgia for a shared industrial past, and stability amidst socioeconomic change. Place attachment to 'home' is particularly painful during times of post-industrial transition: in the case of Walker, people's homes are under threat of demolition with imminent City Council-led regeneration of the community; and in the case of Highland, houses are located on contaminated and economically unviable land. Drawing in both cases on semi-structured interviews with a range of local people between 2005 and 2007, this paper argues that narratives of place attachment - of 'devastation but also home' - reveal some of the contradictions and uncertainties of living through difficult processes of social and economic change.
\end{abstract}




\section{Introduction}

This article examines place attachment to 'home' in the context of disruptive post-industrial change, where homes and communities have come under threat from demolition or toxic contamination. The concepts of 'place identity' and 'place attachment' have emerged as core themes in human geography in relation to themes of mobility, community bonds, and gender relations (Massey 1994; Gustafson 2001; Tuan 1977; Relph 1976; Cresswell 1996; McDowell 1999). Place attachment has also been theorised within the environmental psychology literature (Proshansky 1978; Brown, Perkins, and Brown 2003; Giuliani 1993; Gustafson 2001) to refer to the relationship between self and place as a form of individual socialisation and as part of a collective identity. This article situates the notion of place attachment in relation to the sociological material culture literature on the complex social relationships between people and artefacts, and the cultural meanings embedded in the material world (cf. Lucas 2002; Buchli 2002). In particular, this research draws on a growing material culture literature on the 'home' (cf. Hurdley 2006; Mallett 2004; Januarius 2009; Miller 2001) which focuses on the construction of the 'home' through consumption, contested meanings of 'home' and 'house', performances of the self, constructions of gender and identity, and notions of the ideal or romanticised 'home'.

This research forms part of a larger study of the landscapes and legacies of industrial ruination. Three case studies of old industrial sites were selected from three different cities and regions of the world where deindustrialisation has been most pronounced: the North of England, the old industrial cities of post-socialist Russia, and the 'Rust Belt' of North America. The rationale for selection of case studies was based on the criteria that each case would be: 1) representative of an old industrial area which had experienced significant 
deindustrialisation and had yet to 'recover'; 2) representative of a different type of manufacturing-based industry; 3) located in a different national context within a similar-sized conurbation; and 4) not as widely researched as other 'exemplars' of industrial decline. ${ }^{1}$ Research in each case involved site and ethnographic observations, analysis of documentary and photographic materials, and approximately thirty semi-structured interviews with a range of local people, including workers, residents, ex-workers, trade union representatives, government officials, activists, and community and voluntary sector representatives. This research was conducted between 2005 and 2007, and all interviewees have been kept anonymous or given pseudonyms to protect their identities.

The theme of conflicted place attachment-of devastation but also home- emerged in all three cases, but for the purposes of this paper, I will focus on two cases where this theme was the most evident: Walker, Newcastle-upon-Tyne and Highland, Niagara Falls, United States. The ethnic profiles of each case are different, as Walker is predominantly white and Highland is predominantly black. The local contexts of community development are also different: the community in Walker is faced within imminent City Council-led regeneration and housing demolitions, whereas the most pressing concern for the community in Highland is the removal of contamination and abandoned industrial buildings. Despite these local differences, at the time of my research (2005-2007), Walker and Highland were both deprived areas adjacent to old industrial sites, and place attachment to 'home' was a prevailing theme in both cases. Moreover, both communities were formerly based on a traditional Fordist model of working-class family life, with men working in the shipyards or the chemical factories and women staying at home and raising children. The two communities also had a long history of mutual support between families and neighbours, with adult family members (fathers,

\footnotetext{
1 'Exemplary' cities of industrial decline include Manchester and Detroit, cities which have become symbols of deindustrialisation.
} 
mothers, brothers, sisters) living in close proximity to one another. The importance of 'home' for residents in both cases relates to concepts of family, but with the decline of male manufacturing work, the rise of female employment in services, and the fragmentation of the 'nuclear family' in the postfordist years, concepts of family and 'home' also represent a form of nostalgia, a way of trying to hold onto fading social structures amidst socioeconomic change.

The concept of place attachment in areas of industrial decline raises some key questions. In the economic context of low employment opportunities, physical dereliction, and trends of depopulation, why do people still attach great value to their homes and communities? What is the value of place attachment to individuals, families and communities? What is lost when people have to be mobile? This research on the theme of devastation, but also home suggests that something is lost not so much through either mobility or fixity, but when people have limited choice, based both on economic structures and on conflicted feelings of place attachment and despair over economic realities of industrial decline. In the case of Walker, people's attachment to their homes stood as a barrier to proposed neighbourhood regeneration, and in the case of Highland, the existing negative environmental and economic factors in the area (close proximity to heavily contaminated abandoned industrial sites) represented strong barriers to community redevelopment, regardless of people's local attachments. An analysis of place attachment in areas of industrial decline draws attention to the social and psychological impacts of uncertainty, disruption and stress of lived experience through difficult economic transition. 


\section{Place attachment, community and home}

This research focuses on specific communities or residential neighbourhoods adjacent to sites of industrial ruination. Studies of particular communities and neighbourhoods have a long and varied history of scholarship, and there have been a number of classic studies of disadvantaged (working class; ethnically segregated) communities and neighbourhoods in particular (cf. Young and Willmott 1957; Bell and Newby 1971; Winson and Leach 2002). The concept of 'community' has been criticised as problematic because of its relationship to romanticised and nostalgic notions of social cohesion and place identity, and its tendency to represent 'neighbourhoods as relatively class-homogenous, small-scale, easily delineated areas with clear borders, hosting relatively cohesive communities.' (Blokland 2001: 268) While I use the concept of community within my research, I recognise that this is a contested terms with political connotations.

The concept of 'home' is closely wrapped up with the concept of 'community', and it also carries contested and contradictory meanings. Mallett (2004: 65) argues that 'home' is a multi-dimensional concept, asking: 'Is home (a) place(s), (a) space(s), feeling(s), practices, and/or an active state of state of being in the world? Home is variously described as conflated with or related to house, family, haven, self, gender, and journeying.' Mallett concludes that the experience and study of 'home' relates to all of these themes, and that research on 'home' can be value-laden depending on different contexts and motivations. For example, the 'home' is a political terrain of struggle over gender roles and domestic expectations; the conflation of 'house' and 'home' encourages a capitalist culture premised on home ownership; and the association between 'family' and 'home' relates to conservative ideologies about preserving traditional nuclear family 'values' (Mallett 2004). Recent literature on the material culture of 
the 'home' has focused on interior design, home possessions, mantelpieces, photographs, radios, and other contents of the home (Hurdley 2006; Januarius 2009; Miller 2006). Much of this literature focuses on the construction of home and personal identity through consumption. By contrast, this research examines homes in a different context: homes under threat of demolition, deterioration, dislocation and/or contamination. These are not new homes, and their role in the construction of personal identities is largely in the past.

Place identity, as distinct from individual identity, is an important concept in considering the notion of 'home' within the context of this research. The concept of place identity has been explored within the field of human geography to discuss a range of issues around people's attachments, memories and identities surrounding place (Massey 1994; Gustafson 2001; Tuan 1977; Relph 1976; Cresswell 1996; McDowell 1999). Tuan (1977) was among the first theorists to discuss the affective bond between people and place; he termed this 'topophilia'. Cresswell (2004) argues that for many, the idea of home is the most familiar example of place and its significance to people, and he connects the centrality of home in humanistic and phenomenological approaches to place with Heidegger's focus on 'dwelling' as the ideal kind of 'authentic existence'. Feminist geographers such as Gillian Rose (1993) have criticised romantic notions of home as an ideal place: ‘...[Tuan's] enthusiasm for home and for what is associated with the domestic, in the context of the erasure of women from humanistic studies, suggests to me that humanistic geographers are working with a masculinist notion of home/place' (Rose 1993: 53). Massey (1994: 119) has argued that there is "no single simple "authenticity" - a unique eternal truth of an (actual or imagined/remembered) place or home - to be used as a reference either now or in the past'. In other words, place and home identities are never stable, fixed, or bounded, but they are always constructed. 
There are a number of different definitions of place attachment within the literature, although most definitions emphasise some form of an affective bond between people and landscape. Low (1992: 165) provides a useful distinction between cultural and psychological definitions of place attachment: 'Place attachment is the symbolic relationship formed by people giving cultural shared emotional/affective meanings to a particular space or piece of land that provides the basis for the individual's and group's understanding of and relation to the environment.' The concept of place attachment used in this paper follows this cultural definition but goes further: place attachment is deeply related to social and economic processes, and place itself is not simply a 'particular space or piece of land', but rather, it is 'inhabited'. Cresswell (2004: 10-11) draws a distinction between landscape and place, arguing that place is inhabited, whereas landscape lacks people: 'In most definitions of landscape the viewer is outside of it. This is the primary way in which it differs from place. Places are much things to be inside of... We do not live in landscapes - we look at them.'

The phenomenon of place attachment has been addressed mainly within two contexts, most notably within the environmental psychology literature. The first context relates to the psychological effects of residential mobility, particularly in cases of forced relocation. In a classic study of a working-class area in the West End of Boston, Fried (1963) argued that residents had a strong place attachment to their community despite the poor quality of residential housing. He showed that in areas of urban decline, there is not necessarily a decrease in place attachment. Moreover, he argued that the psychological affects of relocation were disruptive for the West End residents' sense of continuity in life, and the residents continued to feel place attachment even after relocation. Other scholars have also argued that there are negative psychological effects associated with residential mobility, including a 
sense of 'rootlessness', 'placelessness', and a lack of continuity and social cohesion (Altman and Low 1992; Relph 1976; Tuan 1977). However, recent scholars have contested the negative psychological effects of mobility. They argue that there can be positive effects of both mobility ('routes') and place attachment ('roots') which are not necessarily opposed but 'intertwined' (Clifford 1997; Gilroy 1993; Gustafson 2001).

The second context in which place attachment has been studied is related more directly to community studies and community development in areas of urban decline. Fried (2000: 193) has extended his analysis of place attachment in poor communities to make a more general claim: 'Attachment to place is a characteristic feature of life in many poor, ethnic, immigrant communities. The development of a sense of spatial identity is a critical component of attachment experiences in such local areas.' Some scholars have argued that place attachment in depressed neighbourhoods could function as a form of social and community cohesion that could be used as a policy tool in neighbourhood revitalisation. (Brown, Perkins, and Brown 2003) As Fried has suggested, the phenomenon of place attachment in areas of industrial decline is neither surprising nor novel in itself. However, it is relevant for my own research for understanding a different set of issues, specifically how relationships between people and places are reflective of lived experiences of post-industrial change.

\section{Walker, Newcastle-upon-Tyne}

The city of Newcastle-upon-Tyne has long been associated with deindustrialisation, particularly since the decline of shipbuilding in the 1970s and 1980s. In 1999, Newcastle City Council attempted to address issues of depopulation, unemployment and socioeconomic deprivation by branding itself as 'competitive Newcastle', launching a controversial ten-year 
economic redevelopment plan entitled 'Going for Growth'. This city-wide plan was the subject of much debate, as it sought to replace old housing stock with middle-class homes in an effort to retain population, raising concerns that working class populations would be pushed out (Cameron 2003; Byrne 2000). The most recent urban renewal efforts in the area have been concentrated on the derelict land of Gateshead Quays, with the 2002 transformation of the 1950s Baltic Flour Mill into the Baltic Contemporary Art Gallery, the Millennium Bridge which connects Newcastle and Gateshead, and the recently opened (2005) Norman Foster designed Sage Music Centre with a curved glass exterior. This strategy of arts-led-regeneration has been heralded as a good example of post-industrial renewal. However, some critics have argued that the low-paid and female-dominated 'call centre' jobs lack long-term prospects for economic growth (Richardson, Belt, and Marshall 2000), particularly since the call centre industry has shifted to India, amongst other places in Asia, in recent years. In addition, the 'night-time' party culture in Newcastle and the location of Metro Centre, 'one of Europe's largest indoor shopping and leisure centres' in neighbouring Gateshead, offer only limited regional economic growth, as they are based on consumption rather than production, and much of the money comes from within the North East rather than outside the region (Hollands and Chatterton 2002).

In sharp contrast with the 'regenerated' city centre of Newcastle, Walker remains stigmatised as an area marked by industrial decline and by high levels of socioeconomic deprivation. Walker is a residential area situated in the East End of Newcastle-upon-Tyne. The East End of Newcastle developed in the late nineteenth century to house industrial workers in shipbuilding, engineering, coal mining, iron, and chemical and glass works. Coal mining had collapsed by the mid-twentieth century, and shipbuilding along the River Tyne (along an area now known as Walker Riverside) began to decline dramatically in the 1960s and 1970s, with 
the last shipyard Swan Hunter's closing in 2006. Population loss during the past thirty-five years has been more severe in Walker than in Newcastle as a whole, dropping from 13,035 in 1971 to 7725 in 2001 . The slow and steady erosion of heavy industries in Walker has been accompanied with neighbourhood decline, and the area contains numerous abandoned and derelict residential and industrial buildings. The Walker ward ranked the worst of all 26 wards in Newcastle and thirtieth worst of all 8414 wards in England against the 2000 English Indices of Deprivation (Noble, Wright, and Dibben 2000).

At the time of my research (June 2005- March 2006), seventy percent of the total housing stock in Walker consisted of local authority housing, much of which was built during the 1930s. These houses were originally built to accommodate people who worked in the shipyards along the riverside. However, the connection between the Walker community and the Walker Riverside has been broken both economically and physically, as few people work in the remaining industries on the riverside, and residential area is now physically separated from the industrial riverside area by a major road and by security gates and fences. Walker Riverside has been the target of Newcastle City Council regeneration efforts dating from 2001, with the stated aim of attracting new population to the area and reversing the retreat of public and private services from the area. Whereas a similar process of regeneration and relocation occurred in the West End of Newcastle, Walker Riverside proved to be more difficult a case because of local people's attachment to their homes and community. After years of contestation within the community over proposed demolitions of council houses, Walker Riverside regeneration plans finally started to go ahead in 2006 under 'option three', which involved 'major impact' in spatial form for the community. My research focuses on local resident's place attachment to their community as a whole and to their individual homes 
during the difficult early phases of transition, particularly the homes under threat of demolition in the area of Pottery Bank.

\section{Home and community under threat}

Traditionally, Walker is a predominantly white, working class area, like the North East as a whole. According to the 2001 Census, $97.2 \%$ of the population in Walker was white, as compared with $93.1 \%$ of the population in Newcastle and $92.1 \%$ in the United Kingdom. Community solidarity and cohesion is based around these white, working class families, most descended from shipyard workers. A number of families and individuals have left Walker in the past decades, so the people who remain are either those people who have chosen to remain or else those have been unable to move due to financial or personal constraints. Thus, the resilient character of the community can in part be explained by the fact that its population consists of people who have already remained and persevered through times of economic trouble.

On the surface, in many ways, the structure of community and family networks in Walker reflect similar patterns to Young and Willmott's (1957) study of the (then) white workingclass neighbourhood of Bethnal Green in East London. Walker also represents a traditional white working-class community with roots in an industrial past. Extended families in Walker often live within blocks of one another, and the notions of family and community are important for many residents. Indeed, Young and Willmott (1957: 186) concluded that place attachment to the East End of London was related to family and kinship ties: 'The view that we have formed and tested more or less daily for three years is that very few people wish to leave the East End. They are attached to Mum and Dad, to the markets, to the pubs and settlements, to Club Row and the London Hospital.' One could draw a similar conclusion 
about the importance of family and kinship to place attachment in the case of Walker. However, place attachment in Walker can also be framed as a yearning for stability and continuity amidst disruptive social and economic change (as Fried, 1963, has argued), and as an idealised vision of community projected onto a turbulent social and economic reality.

Many interviewees referred in different ways to the strong sense of community in Walker. A Labour City Councillor for Walker who was an opponent of proposals for regeneration in Walker referred to the strength of family connections in the community in Walker, noting that the same families tend to live within the same street for generations, and the fact that local people tend not to travel, even the younger generations. One could 'look at it as a form of stagnation', he said, but also as 'a strength and an asset' (Interview, 30 Aug 2005). During a walk around Walker with Tina, a Walker resident, mother of two, and worker in the community and voluntary sector, Tina illustrated the close community and family networks in Walker: she knew the people, places, politics and local history of Walker in intimate detail, and she showed me her house and the houses of her mother, grandmother and brother, all within a couple of blocks (21 Mar 2006). Another interviewee, a resident of Pottery Bank whose house was under threat of demolition, described how her father's, mother's, and children's homes were all within doors of one another, and thus the impact of demolition and relocation would be 'soul-destroying', as it would separate the family (Interview, 12 Sep 2005). 


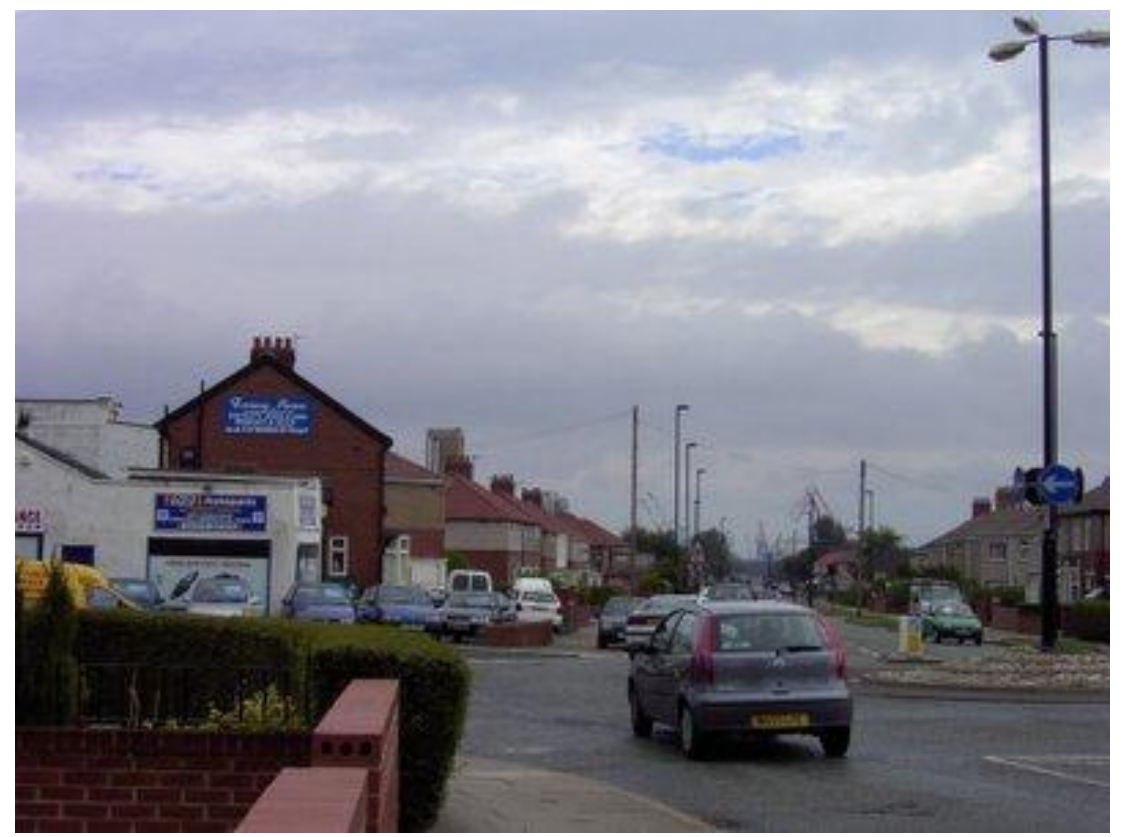

Figure 1 Walker residential area with riverside cranes in the distance, August 2005.

Walker residents expressed particularly strong attachments to their physical homes. In fact, it was the strength of local attachment to 'community' and 'home' amongst local residents that prevented a regeneration process in Walker from going ahead as planned in 2001 under the Newcastle City plan, 'Going for Growth'. The regeneration plan involved significant housing demolitions within the community, and the residents whose houses faced demolitions were strongly opposed. Although the houses were built as Council homes, many of the residents had worked hard to buy their homes and had taken great efforts to decorate and refurbish them over the years. It took five years and numerous 'community engagements' and 'community consultations' for Newcastle City Council to be able to advance with the regeneration plans (at the beginning of 2006). A Labour Councillor for Walker described how residents were up in arms about the proposed demolition of their homes under the City Council's regeneration plans, particularly in Pottery Bank, a residential area next to the River Tyne which would be a prime location for the development of modern riverside flats 
(Interview, 30 Aug 05). ${ }^{2}$ Rather than refurbishing the 1930s houses, the houses would be demolished and replaced, and local people would be relocated to different houses within the Walker area.

The Cambrian show homes were set up by Newcastle City Council as examples of new housing for the area in general, targeted not only at replacing people's demolished homes, but also at attracting newcomers to the area. The Cambrian area was already an area with vacant land and hard-to-let properties, so it had been deemed by the City Council to be an appropriate 'starting point' for regeneration. However, few local residents would be able to afford to move into new homes in the same area once it had undergone regeneration and redevelopment. The Labour Councillor described the Cambrian show homes as "new ecofriendly cardboard boxes' that were 'small, cramped, flimsy...' and would likely last only twenty years, and several residents echoed this attitude. For example, one resident argued:

We don't want to be taken out of the community, and we certainly do not want the monstrosities they have got on Church Street (the Cambrian homes). We don't want those buildings, we don't want them shoeboxes, we've got good strong family homes and we want to keep them. We don't want them shoeboxes that you can't do nothing with, you can't swing cats in. (Interview, Pottery Bank resident, 12 Sep 2005)

\footnotetext{
${ }^{2}$ Newcastle City Council regeneration plans for Walker were originally proposed under a Labour City Council in 2000. When the City Council changed hands from Labour to the Liberal Democrats in June 2004, the Liberal Democrats picked up on the regeneration plans already in place under Labour. However, after the transition, Labour Councillors fought with the Liberal Democrats over the regeneration plans for Walker and sided with residents 'against demolition', particularly since Walker is traditional Labour territory.
} 


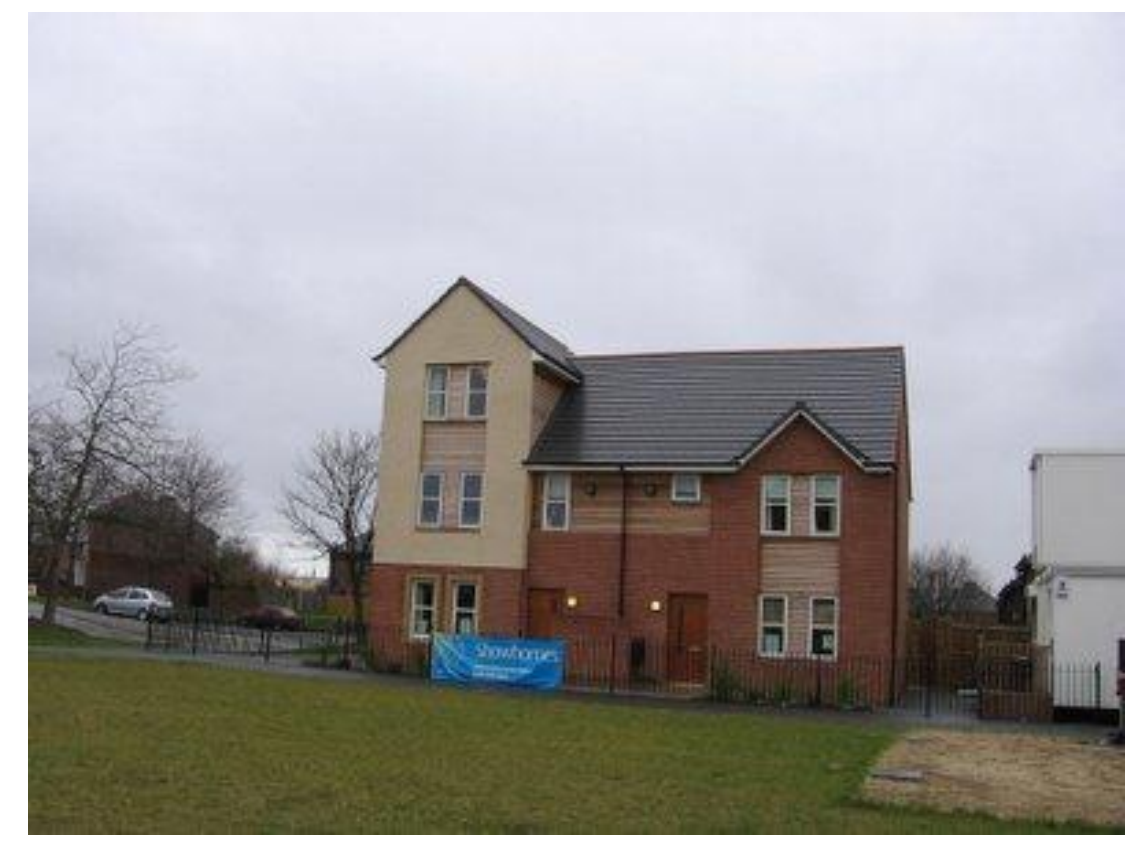

Figure 2 Cambrian Show Homes, Walker, March 2006.

Since its initial failed attempts at regeneration in 2001, Newcastle City Council had done a series of consultations with the 'community' in Walker in order to obtain the consent of the population. However, the City Council kept delaying their 'answer' about whether the homes would be demolished or not until 2006, when the 'third option' was finally approved, with the most significant amount of proposed demolitions and change for the community. One Pottery Bank resident expressed frustration with the experience of waiting for an answer from the City Council about potential demolitions:

All we want to know is a straightforward answer, yes or no, are they standing up or are they coming down? ...I jokingly said, didn't I, last year that if we haven't got an answer by November (2005), I says I'm going to take part in legal history because I would take Newcastle City Council to court for stress, for compensation, for payment, for stress, for nerves, for sleepless nights. For all the residents: it's mental cruelty; it's psychological cruelty. (Interview, Pottery Bank resident, 12 Sep 2005) 
This interviewee underlined her own perceived lack of voice within the process of regeneration in the community by presenting the idea of taking legal action over the psychological impacts of living with uncertainty as a 'joke'. However, her point about mental and psychological cruelty was a profound one: several residents complained about how the uncertainty of the future of their homes impacted their health, leading to stress, anxiety, depression poor mental health, panic attacks, and a feeling of inability to do anything with their homes - sell them, re-paint them, furnish them, or anything at all (Interviews, Pottery Bank residents, 12 Sep 2005). A similar view was expressed by an elderly woman at the Thomas Gaughan Community Centre in Pottery Bank who lived in one of the homes set to be demolished, a home she had lived in for thirty-one years: 'People there won't let me know when, how long's it gonna be before they're coming. But they said they're supposed to build houses on Pottery Bank before they pull them down and I'm hoping they're going to keep that promise.' (Interview, 22 Mar 2006) Her story is filled with a sense of resignation in the face of change.

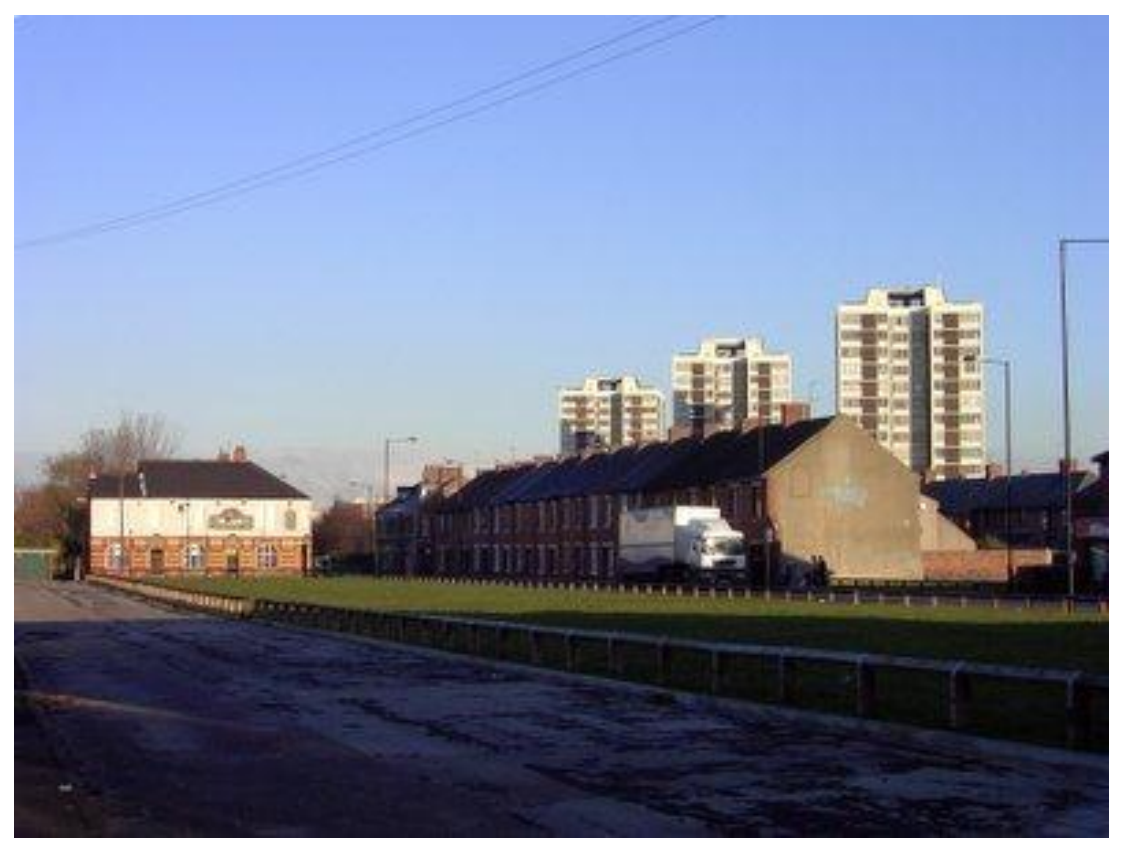

Figure 3 Houses and pub facing demolition, Walker Riverside, March 2006. 
The residents were not only concerned with their own homes and stories; they were also concerned about their neighbours. On resident reflected on the importance of the home as an enduring feature of one's life, particularly in the context of old age:

I know a couple, they got married when they were 18, and that was their first house. One of them, the oldest one was 89 about three years ago, and they've lived in that house all their lives, brought their daughter up, and they don't want to go. All their faculties about them, you know, old people, you expect to end your days in that home. It's not just a house, it's not just an estate, it's a home. And it's all their life, past, present and future. You can't do that to people. (Interview, 12 Sep 2005)

\section{In The Corrosion of Character: the Personal Consequences of Work in the New Capitalism} Sennett (1998) highlights the difficult personal experiences of working in the uncertain and risk-laden context of the new 'flexible' economy, arguing that the lack of predictability, loyalty and long-term relationships between workers and employers, makes it difficult to maintain a defining narrative of one's working life. The loss of a 'home' through postindustrial change also reflects a break in the narrative of one's life, a narrative rooted in certain expectations about family and community life, and the process of ageing.

However, the notion of solid families and a strong community anchored in long-standing homes presents a rather idealised picture of life in Walker, and some of the tensions within the wider community are worth reflecting upon. Whilst highlighting the strength of the Walker community, local interviewees also referred to a fear of incidents of crime and vandalism, problems of drug and alcohol abuse, and rivalries between different neighbourhoods (Interviews with local residents: 12 Sep 05; 22 Mar 06). They lamented the decline of shops and services in the past thirty years and the lack of choice for young people in the area and mentioned that local shopping was overpriced and lacking in fresh fruits and 
vegetables. In an ethnography of young subcultures in North East England, Anoop Nayak (2003) analyses 'Geordie' identity through the lens of class and race. Nayak argues that it is a fallacy to presume that racism is absent from predominantly white areas, and traces complex histories and trends in race relations in the North East. Indeed, in the case of Walker, the issue of racism and difference has become increasingly integral to an analysis of community since the 2001 Census. The dynamic between the primarily white, working-class community of Walker, with its history of close families and networks, and the primarily black African asylum seekers who have arrived in Walker since 2000, has introduced new challenges to community identity, with several incidents of racism. Asylum seekers were placed in 'hardto-let' homes in the most deprived parts of Walker and neighbouring Byker, such as high-rise concrete apartments near the run-down Church Walk shopping area, already associated with drugs and social disarray before the arrival of the asylum weeks. Thus, the geography of place attachment to homes and community in Walker is not straightforward nor is it evenly spread: it relates to particular homes and to particular visions of family and community.

\section{Highland, Niagara Falls, New York}

Niagara Falls, New York shows visible signs of industrial abandonment and dereliction. Over the last forty years, the city has declined from 120,000 people to just over 50,000 people. More than two hundred companies departed the Niagara region between the 1960s and the 1990s (Newman 2003: 128). Half of the infrastructure in the city, including not only factories but roads, housing, sidewalks, and commercial buildings, is abandoned or in a serious state of disrepair. To mitigate these losses, there have been some government and municipal-led brownfield redevelopment initiatives, but there remain many abandoned and contaminated industrial sites and decaying urban neighbourhoods today. The city of Niagara Falls, Ontario in Canada has surpassed Niagara Falls, New York as a tourist destination. The Highland 
community, situated on the north edge of the City of Niagara Falls, is a stark example of a contaminated old industrial area with serious socioeconomic and health implications for the adjacent community.

Highland is one of the poorest communities in Niagara Falls, a largely African-American area which is physically separated from the rest of the city by railway tracks on one side and the city border on the other. Four abandoned chemical plants are located in the Highland Avenue area, in close proximity to residences, and a few partially working factories continue to function in the area. The area developed during the post-war period, when jobs in chemical factories were booming, and African-American people from the South were moving to find work. They were placed in this area on the edge of the city directly adjacent to the chemical factories, for they weren't allowed to live amongst white people in the downtown, and gradually they built their own homes and their own community. They generally worked in lower level factory jobs, as better jobs were given to white people. The environmental and racial segregation of Highland Avenue arguably represents an example of what is known as 'environmental racism' (Bullard 1993; Clairmont and Magill 1974; Cole and Foster 2001), as the proximity of the African-American community to toxic contaminated sites was not an historical accident. With the decline of industry, many people have left, and those who remain are mostly widows, because their husbands died early from working in the plants. However, the people who remain in the community expressed considerable attachment to their homes, as their homes are all they have left. 


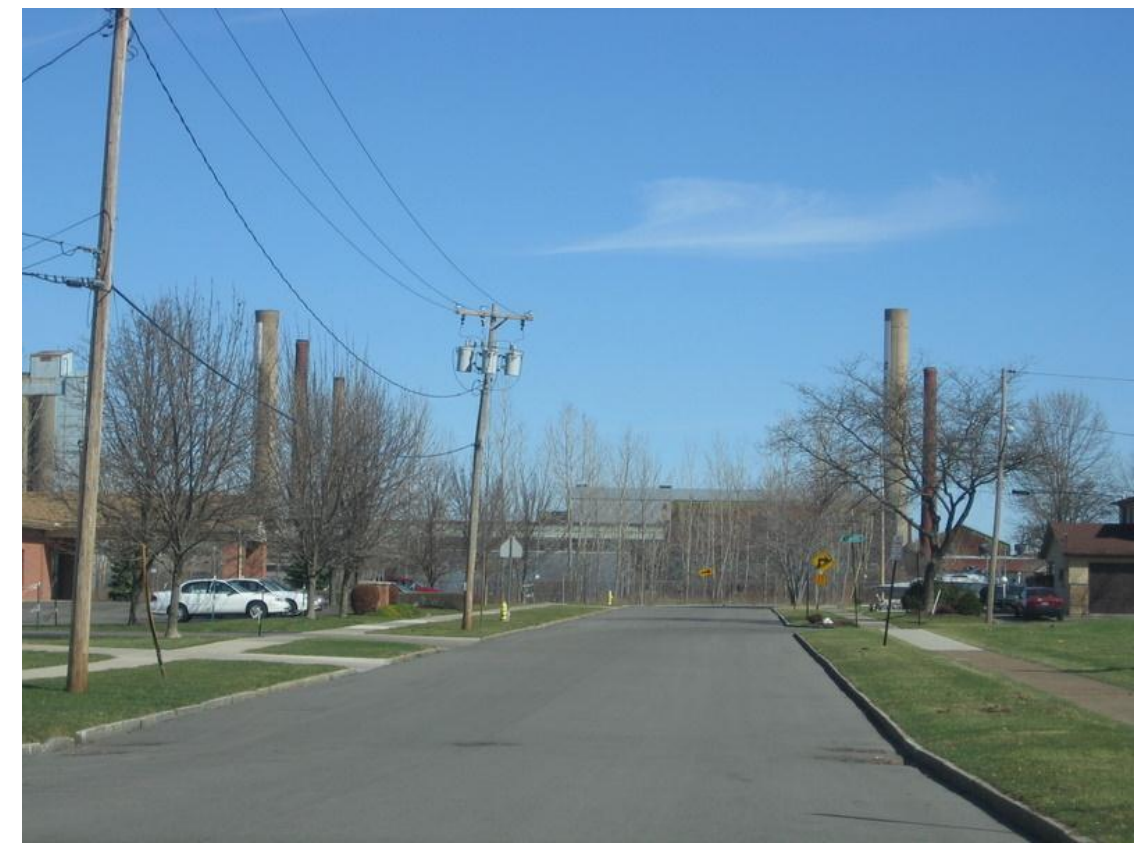

Figure 4 Highland Avenue neighbourhood: smokestack views, March 2007

The Highland area was taken up by the City Council as a pilot project when the vast Union Carbide factory became derelict about ten years ago and the City of Niagara Falls inherited it. In 1998, as part of the initial brownfield pilot project, 5.5 acres of the Union Carbide site were assessed by the City, with some ground contamination and asbestos detected (Henry 2001). However, this pilot project came to a standstill because federal and state funding 'dried up', and only recently has limited funding come back into brownfield redevelopment for further testing (Interview, Senior Planner, Niagara Falls City Council, 21 Mar 2007). Unlike in Walker, the Niagara Falls City Council had no plans for regeneration or redevelopment of the Highland community; it was concerned with the more fundamental problem of what to do with significant contamination and blight. In Walker, the importance of 'home' as sites of family and community stability was revealed through the threat of demolition to people's houses, whereas in Highland, people's homes represented oases of achievement and family endurance amidst hazardous contamination and severe poverty. 


\section{Family, church and community}

Place attachment to 'home' emerged in the Highland community as a symbol of family, church and community within an intensely socially and racially excluded community located in close proximity to contaminated industrial sites. Whereas in Walker, community cohesion was as much of an ideal as a reality, given the number of internal tensions and problems within the 'community', community cohesion in Highland seemed to be stronger and less fragmentary. Highland residents perceived their whole community as one big family. The community was tied together through the shared experience of living with spatial, socioeconomic and racial segregation from the rest of the city, and with extreme poverty, joblessness, health problems, and contaminated land. The historical and contemporary environmental and racial segregation of Highland Avenue could be described as an example of ‘environmental racism' (Bullard 1993; Clairmont and Magill 1974; Cole and Foster 2001), with the African-American residential community 'placed' directly adjacent to chemical factories. Other spatial indicators of the separation of Highland from the rest of Niagara Falls are the railroad tracks over two of the main roads which one must take in order to enter the area, and the boundary of the city.

I went on a driving tour of the Highland community with Carl, an African-American former Highland resident and manager of the Highland Community Revitalization Committee. According to Carl, there is a discrepancy between the way that neighbourhoods are perceived, the way that they are experienced, and the social and economic realities of living in neighbourhoods. He said that the rest of the city of Niagara Falls perceives Highland as an 
area with the largest concentration of low income families and with high rates of crime. This negative image came from the portrayal of the Highland community in the media, Carl argued, for the media often connected stories of crime which happened in other areas of the city back to Highland. In contrast to this stigmatized perception of Highland, he said:

For the families that live here, it's a very different sense of what the community is all about. It's a stronger sense of home... I think that the people that are here have a very strong sense of community among themselves, and I think that almost the poorer they are, there may be a stronger sense of community because they kind of watch out for each other. People will get sick and neighbours will bring them food and make sure that they have something to eat. And then maybe that sense that I have to help this person, because if something happens to me and my family's now all gone, who's going to be there. You know, it's just going to be the neighbours that are left. (Interview, 23 Mar 2007)

During our driving tour of the Highland area, Carl described the history of different homes: who lived in each house, whether they had undertaken home improvements, when people had died or moved, and so on. He also pointed out how close the chemical factories were to people's backyards. His knowledge of the community and the streets was intimate, reflecting a rich local knowledge, but he also situated his knowledge in relationship to the broader context of the city. He pointed out that the Highland area has only about 3000 people, but there are eighteen churches. Carl also showed me neighbouring white communities which become increasingly upscale as they get closer to the Niagara Gorge. 


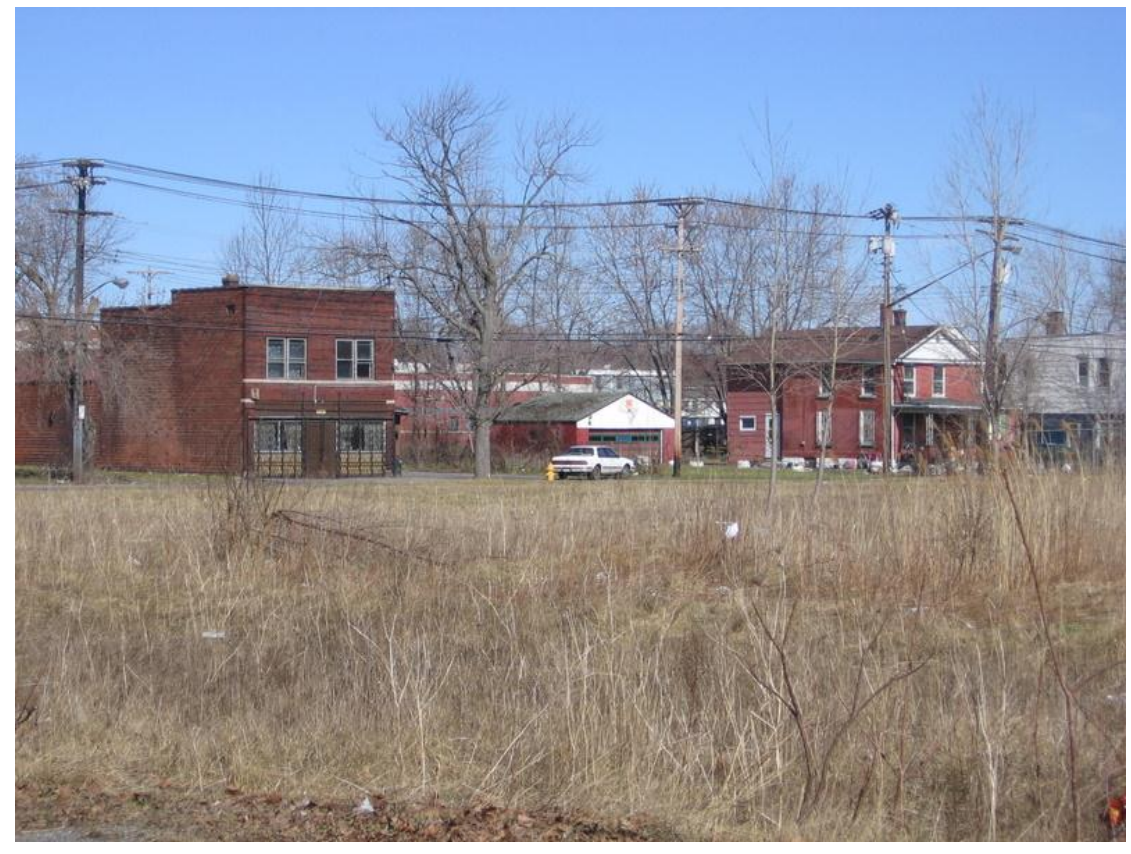

Figure 5 Highland Avenue residences and overgrown brownfield, April 2007.

One of the clearest examples of place attachment to 'home' in Highland is evident in the narrative of Mary, a long-term African-American Highland resident and Baptist minister. Mary moved with her (late) husband and children to Niagara Falls from Alabama in the 1950s. Her husband worked in one of the plants. Together, they had ten children and took great pride in the home that they made in the Highland community. When I interviewed Mary at her home on Virginia Avenue, she was on a respirator and had a bad chronic cough (28 Mar 2007). She also told me that she had cancer and reported no feeling in one of her arms. Regardless of the social and economic problems of crime, drugs, poverty and poor health in the area, she was very positive about her experience of living in a community with close friends and family. Mary said that she's had a good life in Niagara Falls despite the economic hardships, and it was all because of family, church and community. She spoke of the individual homes and families on each street with knowledge of the details of each home and family, and a sense of each street as a unique space. I was struck by the sense of place that Mary evoked in her descriptions of Virginia Avenue: 
But as far as Virginia Avenue runs, there wasn't [sic] when I came here, there was just one, two, three, four, five, maybe six houses here. And that's all. The tall house when you come up around the curve around there, that house was there, and the [family's] house was there, and they had this other house, that light green and dark green house, and then the house next door to me, and the [family's] house, and there was another house up the street there.

She also described the social world on Virginia Avenue as one of a big extended family:

But as far as Virginia Avenue, we've had a neighbourhood, one thing, a very good friendly neighbourhood. We had on Virginia Avenue black club that we was very close with one another. We visited with one another, you know, and had good times in each other's homes. We would have the meetings, and it was like a social club 'cause each family would prepare a nice big meal and we would have our meetings and then we would eat and unite and we was served, and we was like a family here. We supported each other, the Virginia family; we came together and we supported each other. And it's been good living here for me. And my health isn't that good but I'm doing okay.

Even though Mary referred to the 'dump' on which the houses in the area were built, to the old factories in the area, and to her poor health, she did not express much interest in whether the areas were contaminated or not, or in whether the health problems in the area were related to these sites. Mary thought that the health problems in the community were related to age, regardless of whether people had worked in the factories or not. She knew people who had died who hadn't worked in factories and people in reasonably good health who had worked in factories. Her own life in Highland had been a good one, she stressed, despite health problems in later years and the fact that most of the seniors in the area, who she listed at some length, were now dead. Above all, Mary emphasised the strong sense of family and 
community in Highland, and the importance of the churches, which she said work together and are like families too.

For many people in Highland, the importance of home was linked to the concept of family. Several interviewees described the difficulties that families endured over the years in order to be able to afford to build homes and support their families. Carl explained this attachment as follows: 'One of the things that I think is sort of difficult about this city is that the families are families that their homes is sort of all that they have that's left, and no matter what, they don't want to leave their home, they don't want to sell their home' (Interview, 23 Mar 07). People referred with a sense of nostalgia and loss to the structure of families in the past, with the man working in the factory and supporting a wife and children. They lamented the demise of this structure, as it was no longer tenable without the possibility of men gaining full-time high wage employment. Carl explained the impact of the loss of manufacturing jobs on families as follows:

You can find a job that's part-time, that's paying just enough that you can survive, but not really enough to do anything, not enough to really save. Not enough to really feel secure financially and make plans, you know. You hear people say, well, you know, 'I can't afford to get married; I can't afford to do it. Because I'm barely able to take care of myself and I can't take on a wife and children. I can't buy a house.' (Interview, 23 Mar 2007)

Another African-American Highland resident, a former factory worker and community activist, also commented on the change in the Highland community and the erosion of the family home:

We have about a third of the homes [in the Highland community] that we had when the city was booming. Most of those homes have been torn down, burned out and torn 
down. Of the remaining homes, you only have a third of the disposable income that you had. The house that I live in, and I live there alone, used to be a two family home. There were nine people living in that house at one time, now there's one. But you look down the neighbourhood, you still see, there's a house there. You can no longer make the assumption that there's a family there. (Interview, 21 Mar 2007)

Mary echoed these views about the impact of job losses on families:

How can people survive; how can they live? Your whole livelihood is gone if you close the factories and things. You don't have income. My family, my grandchildren, they are leaving as they are graduating and going to college, they leave the city. (Interview, 28 Mar 2007)

The interviewees seemed to wish for a return to the traditional 'Fordist' structure associated with manufacturing and nuclear families. However, they did not express distain for elements of what has been theorised as the post-Fordist social and economic structure (cf. Jessop 1991; Amin 1994) — with different gender roles, different forms of employment, and different consumption patterns. In fact, the 'Fordist' structure was the only one they had experience with, since nothing had come to replace the logic and socioeconomic reality of the heavy industrial era, as the knowledge and service economy had in other cities around the westernised world.

Despite community revitalisation plans in Highland, the family home, the church and the community in Highland continue to exist as havens of solidarity amidst decline, sickness, poverty and contamination. In this case, place attachment is not sufficient for community renewal, as Brown, Perkins et. al. (2003) have suggested, because the costs of clean-up, let alone economic revitalisation, are too high. The lack of economic resources as an obstacle to community redevelopment is particularly evident when framed in the wider context of 
industrial decline, depopulation, and contamination in the City of Niagara Falls, New York. Carl remarked that people in Highland would build very solid and attractive homes in Highland despite the fact that they could not resell them at a fraction of what they cost to build (Interview, 23 Mar 2007). They built and refurbished their homes in Highland because of their long-standing attachment to the community. People's homes in Highland were not under threat of demolition, but their livelihoods, their business district, their health, and everything else except for their homes and their networks of community solidarity, had gone.

\section{Conclusion}

In both Walker, Newcastle-upon-Tyne and in Highland, Niagara Falls, New York, people constructed their 'homes' of the past and present in a way which reflected a sense of devastation but also home. In Walker, residents regarded the strength of their community as something which had endured through socioeconomic decline; it was something which they were proud of and would fight to preserve through their battle to keep their physical houses from being demolished. At the same time, local people in Walker expressed deep awareness of the social and economic deprivation within their community, and related social issues such as drug and alcohol use and crime. For residents in Highland, homes represented a sense of family and community achievement, yet they were imbued with a sense of nostalgia for lost social structures of family and work and with the long-term experience of spatial, social and racial exclusion.

This research relates to the literature on the psychological impacts of residential mobility in the case of Walker, Newcastle-upon-Tyne, in that residents faced threat of dislocation from their homes, and they suffered from depression, anxiety and stress as they waited to find out 
about the future of their homes. In the case of Highland, Niagara Falls, residents were not faced with relocation but rather faced negative health and socioeconomic effects by remaining in their community. In Highland, local residents continued to build new homes within the area or to add improvements to their existing homes despite low property value and health risks associated with proximity to contaminated old chemical factories. The research also suggests that community cohesion through place attachment is not necessarily a good policy tool for community development, as some of the literature has suggested, as it is difficult to separate the 'devastation' from the 'home' in areas of industrial decline, particularly in relation to contaminated areas and areas marked by dereliction and stigmatisation.

Despite the contradictions and conflicts of place attachment in areas of industrial decline, each case also pointed towards positive potentialities of place. These built on particular identities and capabilities distinctive to each place: 1) the ability to resist and shape local politics around redevelopment and change, as in the case of Walker; 2) the ability to work together and support one another in the face of hardship, as in the case of Highland. As Hooks (1991: 147) argues, memories of the traditional and nostalgia are not necessarily a reactionary and conservative; rather, they can be important because they 'illuminate and transform the present.' The diverse perspectives and challenges of people who live through processes of deindustrialisation have significant implications for how we might tackle issues of industrial decline.

\section{Acknowledgements}


I would like to thank the anonymous reviewers for their invaluable suggestions. I would also like to extend thanks to Fran Tonkiss, Richard Sennett, Ash Amin, and the NYLON (New York-London) Research Network. This research was supported by a grant from the Social Sciences and Humanities Research Council of Canada. 


\section{References}

Altman, Irwin, and Setha M. Low, eds. 1992. Place Attachment, Human behavior and environment. New York; London: Plenum.

Amin, Ash, ed. 1994. Post-Fordism: a Reader. Oxford: Blackwell.

Bell, Colin, and Howard Newby. 1971. Community Studies: An Introduction to the Sociology of the Local Community. London: Allen \& Unwin.

Blokland, T. 2001. Bricks, mortar, memories: neighbourhood and networks in collective acts of remembering. International Journal of Urban and Regional Research 25 (2):268283.

Brown, B., D. Perkins, and G. Brown. 2003. Place attachment in a revitalizing neighborhood: Individual and block levels of analysis. Journal of Environmental Psychology 23 (3):259-271.

Buchli, Victor, ed. 2002. The Material Culture Reader. Oxford: Berg.

Bullard, Robert D. 1993. Confronting Environmental Racism: Voices From the Grassroots. Boston, Mass: South End Press.

Byrne, David. 2000. Newcastle's Going for Growth: governance and planning in a postindustrial metropolis. Northern Economic Review 30:3-16.

Cameron, Stuart. 2003. Gentrification, Housing Redifferentiation and Urban Regeneration: 'Going for Growth' in Newcastle upon Tyne. Urban Studies 40 (12):2367-2382.

Clairmont, Donald H. J., and Dennis W. Magill. 1974. Africville: the Life and Death of a Canadian Black Community. Toronto: McClelland and Stewart.

Clifford, James. 1997. Routes: Travel and Translation in the Late Twentieth Century. Cambridge, Mass. ; London: Harvard University Press. 
Cole, Luke W., and Sheila R. Foster. 2001. From the Ground Up: Environmental Racism and the Rise of the Environmental Justice Movement, Critical America. New York ; London: New York University Press.

Cresswell, Tim. 1996. In placelout of place : geography, ideology, and transgression. Minneapolis ; London: University of Minnesota Press.

—. 2004. Place: A Short Introduction. Oxford: Blackwell.

Fried, M. 1963. Grieving for a lost home. In The Urban Condition: People and Policy in the Metropolis, edited by L. J. Duhl. New York: Basic Books.

- 2000. Continuities and discontinuities of place. Journal of Environmental Psychology 20 (3):193-205.

Gilroy, Paul. 1993. The Black Atlantic: Modernity and Double Consciousness. London: Verso.

Giuliani, M. V. 1993. Place attachment in a developmental and cultural context. Journal of Environmental Psychology 13:267-274.

Gustafson, Per. 2001. Roots and routes: exploring the relationship between place attachment and mobility. Environment and Behavior 33 (5):667-686.

Henry, Sherryl. 2001. For developers in Niagara Falls, the honeymoon's just beginning. In Brownfield Success Stories. Niagara Falls: United States Environmental Protection Agency.

Hollands, Robert, and Paul Chatterton. 2002. Changing times for an old industrial city: hard times, hedonism and corporate power in Newcastle's nightlight. City 6 (3):291-315.

Hooks, Bell. 1991. Yearning : race, gender, and cultural politics. London: Turnaround.

Hurdley, Rachel. 2006. Dismantling Mantelpieces: Narrating Identities and Materializing Culture in the Home Sociology 40 (4):717-733. 
Januarius, J. 2009. Feeling at home: interiors, domesticity, and the everyday life of Belgian Limburg miners in the 1950s. Home Cultures 6 (1):43-70.

Jessop, Bob. 1991. Fordism and Post-Fordism: A Critical Reformulation. Lancaster: Lancaster Regionalism Group.

Low, Setha M. 1992. "Symbolic Ties that Bind: Place Attachment in Plaza." In I. Altman and S.M. Low (eds.) Place Attachment, Human Behavior and Environment. 165-185. New York and London: Plenum.

Lucas, Gavin. 2002. Disposability and dispossession in the twentieth century. Journal of Material Culture 7 (1):5-22.

Mallett, S. 2004. Understanding home: a critical review of the literature. Sociological Review $52(1): 62-89$.

Massey, Doreen. 1994. Space, Place and Gender. Minneapolis: University of Minnesota Press.

McDowell, Linda. 1999. Gender, identity and place : understanding feminist geographies. Cambridge: Polity.

Miller, Daniel. 2001. Home possessions : material culture behind closed doors. Oxford: Berg.

- 2006. Things that bright up the place. Home Cultures 3 (3):235-250.

Nayak, Anoop. 2003. Race, Place and Globalization: Youth Cultures in a Changing World. Oxford: Berg.

Newman, Richard. 2003. From Love's Canal to Love Canal. In Beyond the Ruins: the Meanings of Deindustrialization, edited by J. Cowie and J. Heathcott. Ithaca and London: Cornell University Press.

Noble, M, G Wright, and C Dibben. 2000. The English Indices of Deprivation 2000. London: Office of the Deputy Prime Minister. 
Proshansky, Harold M. 1978. The city and self-identity. Environment and Behavior 10 (2):147-169.

Relph, Edward. 1976. Place and Placelessness, Research in planning and design ; 1. London: Pion.

Richardson, Ranald, Vicki Belt, and Neill Marshall. 2000. Taking calls to Newcastle: the regional implications of the growth in call centres. Regional Studies 34 (4):357-369.

Rose, Gillian. 1993. Feminism and geography : the limits of geographical knowledge. Cambridge: Polity Press.

Sennett, Richard. 1998. The corrosion of character: the personal consequences of work in the new capitalism. New York: Norton.

Tuan, Yi-fu. 1977. Space and Place: The Perspective of Experience. London: Edward Arnold.

Winson, Anthony, and Belinda Leach. 2002. Contingent Work, Disrupted Lives: Labour and Community in the New Rural Economy, Studies in Comparative Political Economy and Public Policy. Toronto: University of Toronto Press.

Young, Michael Dunlop, and Peter Willmott. 1957. Family and Kinship in East London, Reports of the Institute of Community Studies; 1. London: Routledge \& Kegan Paul. 